\title{
Helminth infection in Anabas testudineus of three wetlands of Goalpara, Assam
}

\author{
Dimple Das* and M. M. Goswami \\ Department of Zoology, Guwahati University, Guwahati-14 (Assam), INDIA \\ *Corresponding author. E-mail: dimpledas12@gmail.com \\ Received: April 05, 2014; Revised received: July 20, 2014; Accepted: November20, 2014
}

\begin{abstract}
Anabas testudineus (Bloch) is a popular eatable fresh water fish. The fishes infested with helmnthic infection may be died off and the production may be decreased. Besides, the parasites could pass through man and other animals. The occurrence of parasites and their prevalence and intensity in the fish was studied from March, 2012 to February, 2013 in Hasila, Kumri and Urpad wetlands of Goalpara district of Assam. Three trematodes and six nematodes were collected from 309 out of 547 host fish. The trematodes were identified as Asymphylodora kedarai, Brahamputratrema sp., Neopodocotyl sp. and the nematodes were Camallanus anabantis, C.trichuris, C.intestinalus, Onchocamallanus sp., Parascarophis sp, and Cosmoxynemoid nandusi.
\end{abstract}

Keywords: Anabas testudineus, Goalpara, Hasila, Helminth, Kumri, Urpad

\section{INTRODUCTION}

Anabas testudineus is a small fish from Indian water. Being column feeder and larvicidal fish it is used to control mosquito. It is also popular for their lean meat, which contains easily digestible protein and fat of very low melting point and many essential amino acids making them ideal food. So, Anabas enjoys a good market demand in Assam as well as in the north-east region. The importance of parasite is related directly to the fish that may affect the general public health (Hoffman, 1967). Parasitic diseases, either alone or in conjunction with other environmental stresses, may influence weight or reproduction of the host, alter its population characteristics and affect its economic importance (Rohde, 1993).Various studies have been conducted on helminth communities of fish. The influence of parasitic infection in relation to the length of fish has been described by many workers (Fagerholm, 1982; Amin, 1986; Jha and Singha, 1990; Barber, 2005; Pandey et al., 2012 and Dar et al., 2012). Gambhir et al. (2006) studied on new nematode of the genus Cosmoxynemoides from the intestine of Colisa labiosus in Manipur. Geetarani et al. $(2010,2011)$ studied on the nematode parasites of Utra Lake in Manipur. Sangeeta et al. (2010, 2011) studied on the nematode parasites of Oinam Lake in Manipur. Shomorendra and Jha (2003) studied on a new nematode parasite Paraquimperia manipurensis n. sp. from the intestine of A. testudineus (Bloch).Though lots of work have been done to study helminth infection of fish in NE India, very little published reports were found by authors relating to this region which made the base for present investigation to find out the helminthic infection in A. testudineus.

\section{MATERIALS AND METHODS}

547 climbing perch, Anabas testudineus were collected from three wetlands viz. Hasila, Kumri and Urpad of Goalpara district, Assam from March 2012 to Feb 2013. Each fish was individually dissected and examined for the presence of parasites separately in body cavity, mesentery, intestine, liver, peritoneal wall, rectum, gills, head and muscle by adopting the methods employed by Mayer and Olsen (1975), Cable (1977), Madhabi et al. (2007). Gills were investigated under a stereomicroscope. The liver was cut into small pieces which were firmly pressed between two thick glass plates, and then examined under a compound microscope. The intestine was dissected by needles and the presence of worms was determined by using a stereomicroscope. The head and muscles were chopped and examined for worms. Nematodes were put in hot water for stretching and then fixed in mixture of $70 \%$ ethanol and $10 \%$ glycerol. Digenean trematodes were fixed in AFA solution (Alcohol-85 $\mathrm{ml}$, formalin-10 $\mathrm{ml}$, acetic acid- $5 \mathrm{ml}$ ). Lectophenol was used to clear the nematodes and permanent slides were made according to Gibson (1984). Identification was carried out by morphological examination, as described by Chabaud (1947), Yamaguti (1958) and Chubb (1980, 1982) and Soota (1983), The prevalence, mean Intensity and abundance or relative density were calculated as per Margolis et al. (1982).

\section{RESULTS AND DISCUSSION}

Out of 547 climbing perch collected from three wetlands of Goalpara district, 309 were infected by 09 species of helminths with an overall prevalence $56.49 \%$. Out of 309 infected fishes, 780 helminth 
parasites were recovered with mean intensity 2.52 and abundance 1.43 (Table 1). The species with the highest prevalence was in Camallanus anabantis (18.6\%), while Asymphylodora kedarai, Neopodocotyl sp, C. trichuris, C. intestinalus, Cosmoxynemoid nandusi, Onchocamallanus sp, Brahamputratrema $s p$ showed $16.5,12.8,12.4,9.1,4.2,3.8$ and $2.7 \%$ prevalene respectively. The species with the lowest prevalence was in Parascarophis sp (1.8\%) as shown in Table 2. The result revealed that $C$. intestinalus showed the highest mean intensity (0.62) at Hasila wetland, while in contrast, Brahamputratrema sp showed the lowest (nil) at Kumri and Urpad wetlands. In this study, it was found that helminth parasites were specific to their habitats since Brahamputratrema sp was collected only from the fish at Hasila wetland. Parascarophis $s p$ and Onchocamallanus $s p$ were not found in fish at Kumri and Urpad wetlands. The findings agree with previous report on the relationship between geoclimatic factors of habitat and prevalence and intensity of the helminthic infection in freshwater fish (Akinsanya et al., 2006). Prevalence of helminthic infestation was found to be higher $(58.89 \%)$ in Kumri wetland (Beel) which is a perennial one than in Hasila (54.39) and Urpad (56.22) which are biannual wetlands. Sarma (2012) also found the same result where he took 2 perennial and biannual wetlands and 1 artificially controlled pond as his study area. Examination of the occurrence of helminths in separate organs revealed that the highest infesting organ of helminths was intestine with $80 \%$ infection followed by the

Table 1. Infection level of helminths from three habitats.

\begin{tabular}{lllllll}
\hline Habitat & FE & FI & NP & P\% & MI & A \\
\hline Hasila & 182 & 99 & 273 & 54.39 & 2.76 & 1.5 \\
Kumri & 180 & 106 & 277 & 58.89 & 2.61 & 1.54 \\
Urpad & 185 & 104 & 230 & 56.22 & 2.21 & 1.24 \\
\hline Total & $\mathbf{5 4 7}$ & $\mathbf{3 0 9}$ & $\mathbf{7 8 0}$ & $\mathbf{5 6 . 4 9}$ & $\mathbf{2 . 5 2}$ & $\mathbf{1 . 4 3}$ \\
\hline
\end{tabular}

$(\mathrm{FE})=$ Fish examined, $(\mathrm{FI})=$ Fish infected, $(\mathrm{NP})=$ No. of parasite, $(\mathrm{P})=$ Prevalence, $(\mathrm{MI})=$ Mean intensity, $(\mathrm{A})=$ Abundance infection in body cavity, peritoneal wall, rectum with $76.9 \%, 62 \%, 58.5 \%$ respectively and in liver, infestation rate was the lowest with just $2 \%$.(Fig.1). Comparing to the results of earlier worker it can be established that environment and habitat play an important role on helminth parasites for infesting specific organ in host body. Luangphai et al. (2004) recorded the highest infestation in muscle and head and the lowest in intestine of $A$. testudineus, whereas in this study, intestine showed the highest infestation rate $(80 \%)$ conformity with Khanam et al. (2011) observed the maximum helminths infestation in the intestine of Macrognathus aculeatus. Binky et al. (2011) recorded only three helminth species with an overall prevalence and mean intensity of $8.82 \%$ and $01 \%$ respectively in $A$. testudineus from Silchar, Assam . In contrast, in present study, 09 helminth species with $56.5 \%$ prevalence and 2.5 mean intensity have been recorded in the same species from Goalpara. Further investigation on this unexplored area on other host will give new light in helminth diversity as well as their infestation level on host.

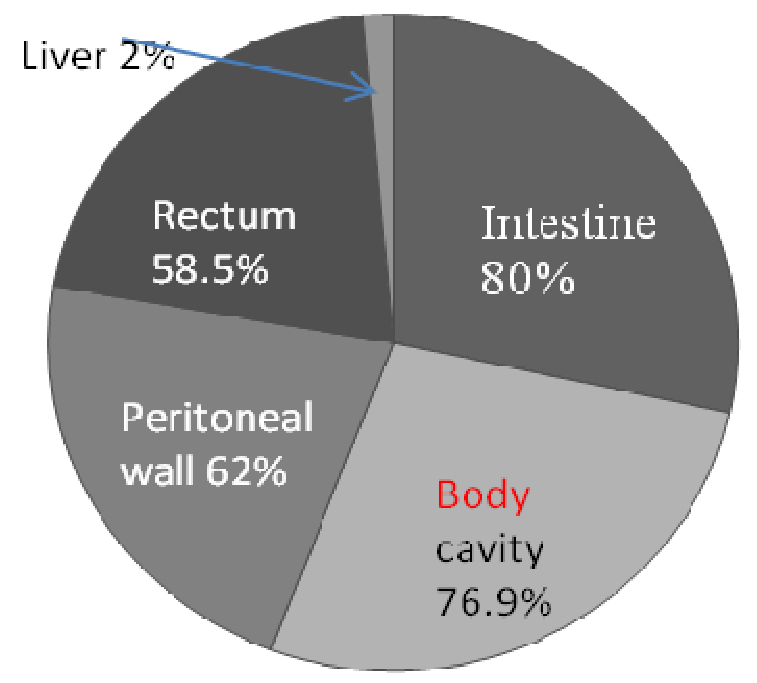

Fig.1. Percentage of helminths infestation in different organs of the fish.

Table 2. Prevalence and mean intensity of helminth species in three wetland habitats.

\begin{tabular}{lcccc}
\hline Helminth species & Prevalence (\%) & \multicolumn{2}{c}{ Total no. of helminths (Mean intensity) } \\
\cline { 2 - 5 } & & Hasila wetland & Kumri wetland & Urpad wetland \\
\hline Asymphylodora kedarai & 16.5 & $36(0.36)$ & $38(0.35)$ & $56(0.54)$ \\
Brahamputratrema sp & 2.7 & $24(0.24)$ & $00(00)$ & $00(00)$ \\
Neopodocotyl sp & 12.8 & $27(0.27)$ & $50(0.47)$ & $48(0.46)$ \\
Camallanus intestinalus & 9.1 & $61(0.62)$ & $27(0.25)$ & $20(0.19)$ \\
Camallanus trichuris & 12.4 & $27(0.27)$ & $56(0.53)$ & $43(0.41)$ \\
Camallanus anabantis & 18.6 & $46(0.46)$ & $57(0.54)$ & $40(0.38)$ \\
Onchocamallanus sp & 3.8 & $30(0.3)$ & $20(0.19)$ & $00(00)$ \\
Parascarophis sp & 1.8 & $09(0.09)$ & $00(00)$ & $06(0.06)$ \\
Cosmoxynemoid nandusi & 4.2 & $13(0.13)$ & $29(0.27)$ & $17(0.16)$ \\
\hline
\end{tabular}




\section{ACKNOWLEDGEMENTS}

The authors are thankful to the Director, ZSI, Kolkata. Thanks are due to Shri S.R. Dey Sarkar and Dr. S.B. Bhattacharya of ZSI, for confirming the identification of helminth species.

\section{REFERENCES}

Amin, O.M. (1986). Acanthocephala from lake fishes in Wisconsin: host and seasonal distribution of species of genus Neoechinorhynchus Hamann, 1892. J. Parasite., 72(1): 111- 118.

Akinsanya, B. and Otubanjo, O.A. (2006). Helminth parasites of Clarias gariepinus (Clariidae) in Lekki Lagoon, Lagos, Nigeria, Rev. Biol. Trop., Int. J. Trop. Biol., 54 (1): 93-99.

Binky, Kh., Shomorendra, M. and Kar, D. (2011). Nematode parasites of Karbhala wetland in Silchar Assam. Biological Forum- An International Journal, 3(2): 18-21

Barber, I. (2005). Parasites grow larger in faster growing fish hosts. International Journal for Parasitology, 35: 137-143

Cable, R.M. (1977). An illustrated laboratory manual of parasitology, $5^{\text {th }}$ ed. Burgess publishing Company, Minneapolis, Minnesota.

Chabaud, A.G. (1947). Keys to the nematode parasites of vertebrates. Keys to sub classes, order and Anderson, Chabaud and Willmott, Royal, Buckr, England. : 17

Chubb, J.C. (1980). Seasonal occurrence of helminth parasite in fishes. Part-iii. Larval Cestoda and Nematoda. Advances in Parasitology. Academic press. London \& New york. 18: 1-120.

Chubb, J.C. (1982). Seasonal occurrence of helminth parasite in fishes. Part-iv. Adult Cestoda, Nematoda and Acanthocephala. Advances in Parasitology. Academic press. London \& New york. 20: 1-292.

Dar Ahmed, Sh., Ahmed, F., Mir, M.R., Dar, J.A., Tak, H. and Kuchai, J.A. (2012). Helminh infection in coldwater fishes of Suru river Ladakh, Jammu and Kashmir, India. Recent Research in Science and Technology. 4(12): 01-04

Fagerholm, H.P. (1982). Parasites of fish in Finland. VI. Nematodes. Acta Academic Aboensis. Ser,-B. 40(6): 1-128.

Gambhir, R.K., Gyaneshori, I. and Tarnita, Th. (2006). A new nematode of the genus Cosmoxynemoides (Nematoda-Cosmocercinae) from the intestine of Colisa labiosus in Manipur, India. Flora and Fauna, 12 (1): 105-107.

Geetarani, B., Shomorendra, M. and Kar, D. (2010). Studies on the intensity of helminth infections with special reference to nematodes in the fishes of Utra Lake, Manipur. National Journal of Life Sciences, 7(2):103-104.

Geetarani, B., Shomorendra, M. and Kar, D. (2011). Diversity of Fish Nematodes of Utra Lake in Manipur. Environment \& Ecology, 29(1):11-13.

Gibson, D.I. (1984). Technology as applied to museum collection: the collection, fixation and conservation of helminths. Syst. Parasitol., 6:241
Hoffman, G.L. (1967). Parasites of north American freshwater fishes. University of California Press, Berkeley $\&$ Los Angeles.

Jha, A.N. and Singha, P. (1990). The occurrence of helminth parasites in relation to size of fish. Bio. Journal. 2 (11):311-316.

Khanam, H., Begum, S. and Begum, A. (2011). Seasonal prevalence, intensity and organal distribution of helminth parasites in Macrognathus aculeatus. Dhaka Univ. J. Biol. Sci., 20(2): 117-122

Luangphai, P., Wongsawad, C., Kumchoo, K. And Sripalwit, P. (2004). Survey of helminths in climbing perch (Anabas testudineus) from San Sai District, Chiang Mai Province. Southeast Asian J Trop Med Public health, 35 (Suppl 1): 288-290

Madhabi, R., Vijayalakshmi, C. and Shyamasundari, K. (2007). Collection, staining and identification of different helminth parasites: A manual of the workshop on fish parasites - Taxonomy capacity building. Andhra University Press, India.

Margolis, L., Esch, G.W., Holmes, J.C. Kuris, A.M. and Schad, G.A. (1982). The use of ecological terms in parasitology (Report on an adhoc committee of the American Society of Parasitologists). J. Parasit., 68:131 $-133$.

Mayer, M.C. and Olsen, O.W. (1975). Essentials of parasitology. $2^{\text {nd }}$ ed. Wm. C. Brown Co. Iowa: 1-303

Pandey, M., Saxena, R.M. and Handa, P. (2012). Demography of helminth parasites in relation to biometic characteristics of Mastacembalus armatus. Journal of Applied and Natural Science, 4 (1): 56-59

Rohde, K. (1993). Ecology of marine parasites, an introduction to marine parasitology. 2nd Edition. CAB International.

Sangeeta, O., Shomorendra, M. and Kar, D. (2010). Diversity of fish nematodes of Oinam lake in Bishnupur District of Manipur. Environment \& Ecology, 28(4A): 2618-2620.

Sangeeta, O., Shomorendra, M. and Kar, D. (2011). Nematode parasites of fishes of Oinam lake, Manipur, India. Environment \& Ecology, 29(1): 183-186.

Sarma, K. (2012). Seasonal incidence of helminth parasite of three selected Murrel fish species of Assam. A thesis submitted to Gauhati University for the award of the degree Doctor of Phillosophy in Zoology in Faculty of Science. Pp: 136-137

Shomorendra, M. and Jha, A.N. (2003). A new nematode parasite Paraquimperia manipurensis sp. from the intestine of Anabas testudineus (Bloch) Uttar Pradesh. J. Zool., 23(2).

Soota, T.D. (1983). Studies on nematode parasites of Indian vertebrates. I. Fishes. Rec. Zool. Surv. India, Occ. Paper No. $544 .:$ : 352.

Yamaguti, S. (1958). Systema helminthum. Vol I. The digenetic trematodes of vertebrates. Part I and II. New York: Interscience Publishers. 